\title{
THE UPTAKE ABILITY OF THE CLINOPTILOLITIC TUFFS OF SAMOS ISLAND, GREECE
}

\author{
Kantiranis N. ${ }^{1}$, Stamatakis M. ${ }^{2}$, Filippidis A. ${ }^{1}$, and Squires $C .{ }^{1}$ \\ ${ }^{1}$ Department of Mineralogy-Petrology-Economic Geology, School of Geology, Faculty of \\ Sciences, Aristotle University of Thessaloniki, 54124, Thessaloniki, kantira@geo.auth.gr, \\ anestis@geo.auth.gr,csquires@geo.auth.grr \\ 2 Section of Economic Geology and Geochemistry, Department. of Geology, National University \\ of Athens, 15784, Athens, stamatakis@geol.uoa.gr
}

\begin{abstract}
The bulk mineralogy and uptake ability of four samples (SA1 to SA4) of clinoptilolite-bearing tuffs from Samos Island, Greece were investigated. The semi-quantitative mineralogical analyses of the samples were determined by powder-XRD (PXRD). The chemical composition of the samples analysed by Atomic Absorption Spectroscopy (AAS), reflected the bulk mineralogy of the samples. The semi-quantitative mineralogy of the samples was found to be in good agreement with their chemical compositions. The uptake ability was measured using the ammonium saturation method (AMAS). The samples consist of clinoptilolite (47-74 wt. \%), micas (muscovite and/or illite) (4-13 wt. \%) and smectite (2-13 wt. \%) and have uptake abilities between 133 and $184 \mathrm{meq} / 100 \mathrm{~g}$. Such materials, especially the clinoptilolite-rich ones, could be used in a wide range and scale of agricultural, aquacultural, industrial and environmental applications.
\end{abstract}

\section{INTRODUCTION}

Zeolites constitute a major class of crystalline hydrated aluminosilicate microporous minerals including both natural and synthetic species (Breck, 1974). Zeolite bearing rocks are important sources of useful materials for several industrial and environmental applications (Mumpton, 1977. 1978; Pond and Mumpton, 1984; Dyer, 1988; Tsitsishvili et al., 1992; Holmes, 1994; Ming and Mumpton, 1995). The crystalline framework of the zeolites is based on a three dimensional network of $(\mathrm{Si}, \mathrm{Al}) \mathrm{O}_{4}$ tetrahedra and extraframework alkali and alkaline-earth cations, which are loosely bound to the anionic charges within this framework structure and can be exchanged for other cations, including $\mathrm{H}^{+}$. Due to their unique structure, zeolites show exceptional physicochemical properties and have been widely used as molecular sieves, absorbents, detergent components, ion-exchanges, catalysts etc. (Merkle and Slaughter, 1968; Barrer, 1978; Gottardi and Galli, 1985; Filippidis et al., 1996; Filippidis and Kassoli-Fournaraki, 2000; Kantiranis et al., 2002).

Zeolite-bearing rocks occur in a variety of geologic settings. Zeolites appear mostly as alteration or authigenic minerals, low temperature-pressure minerals in metamorphic systems, secondary minerals in weathering zones or in vein-deposits. Commercially interesting zeolites are presently limited to authigenic and alteration settings in finely crystalline sedimentary rocks (Mumpton, 1978). Zeolites are widespread in Greece and clinoptilolite is the most common type (e.g. Tsolis-Katagas and Katagas, 1989,1990; Stamatakis et al., 1996; Filippidis and Kassoli-Fournaraki, 2000; Kantiranis et al., 2002).

Clinoptilolite is a high silica member of the heulandite group of natural zeolites and occurs in abundant and easily mined, sedimentary deposits in many parts of the world (Mumpton, 1988). The composition and purity of natural clinoptilolites and therefore their physicochemical properties vary widely between deposits and may even vary within the same deposit (Mercer and Ames Jr, 1978; Kassoli-Fournaraki et al., 2000).

The present work is an exploratory study of the relationship between the bulk-rock mineralogy and the uptake ability of clinoptilolite-bearing tuffs originating from Samos Island, Greece. 


\section{GEOLOGICAL SETTING AND SAMPLE LOCATION}

The precise locations and geological formations of the samples SA1-SA4 on Samos island are presented in Fig. 1. During the Late Miocene, the Aegean Region was characterized by the development of ephemeral shallow basins, in which either marine or non-marine evaporites were locally deposited. The region was volcanically active and several shallow basins were partly filled with volcaniclastic sediments of rhyolitic to dacitic composition.

On Samos Island, two main Neogene basins were developed. The Mytilinii basin situated in eastern Samos and the Karlovassi basin situated in the west (Fig. 1). The pre-Neogene basement of both basins consists of four tectonic units containing marbles, dolomites, quartzites, phyllites, metamorphic basic to ultrabasic rocks, and a younger nappe of diabases, peridotites, cherts, and limestones (Stamatakis, 1989a\&b). The deposits of both basins are presumed to be a continental facies and are Up. Miocene to Pliocene in age (Dermitzakis and Papanikolaou, 1981). A small Pliocene fresh-water basin is developed about $5 \mathrm{~km}$ southeast of the city of Samos (Fig. 1).

During the Miocene, the Karlovassi basin was filled successively with carbonates, ash-fall tuffs and tuffites, marlstones, claystones, siliceous limestones, porselanites (with abundant opal), and cherts (with abundant chalcedony) (Stamatakis, 1989a). At the margin of the basin there are occurrences of rhyolites, dacites, trachytes, and basalts of Neogene age (Theodoropoulos, 1979). These volcanic rocks are responsible for local silicification and kaolinization of the surrounding rocks (Stamatakis, 1989b). The tuffaceous horizons of the Karlovassi basin underwent extensive diagenetic alteration in a saline-alkaline lake environment, resulting in the formation of rocks rich in zeolites and boron-bearing K-feldspar (Stamatakis, 1989a\&b; Pe-Piper and Tsolis-Katagas, 1991; Hall and Stamatakis, 1992) accompanied by evaporate minerals such as colemanite, ulexite, and celestite (Stamatakis et al., 1996).

\section{MATERIALS AND METHODS}

Four bulk samples of zeolite-bearing rocks weighing $\sim 30 \mathrm{~kg}$ were collected from the Late Miocene ash-tuffs of the Neogene Karlovassi Basin, Samos Island. Each sample was ground $(<125$ $\mu \mathrm{m})$, homogenized and separated into three equal portions. The first portion was used to determine sample uptake ability. The second portion was ground further $(<63 \mu \mathrm{m})$ and used for mineralogical analysis. The third portion was powdered and used for chemical analysis.

The Ammonium Acetate Saturation (AMAS) method (Bain and Smith, 1987) was used to determine sample uptake abilities (meq/100g). Precise amounts of the $<125 \mu \mathrm{m}$ portion of each sample (100-150 mg) were added to centrifuge tubes with $10 \mathrm{~mL}$ aqueous $1 \mathrm{~N}$ ammonium acetate $\left(\mathrm{NH}_{4} \mathrm{OAC}\right)$ solution and agitated for 24 hours. The mixture was then centrifuged and the supernatant discarded. This procedure was repeated a further nine times, after which time it was assumed that $\mathrm{NH}_{4} \mathrm{OAc}$-saturation was complete. The sample was then washed five times with $10 \mathrm{~mL} 99 \%$ isopropyl alcohol to remove any excess $\mathrm{NH}_{4} \mathrm{OAC}$ and air-dried overnight. Following $\mathrm{NH}_{4} \mathrm{OAC}-$ saturation, $\mathrm{NH}_{4}{ }^{+}$ions are retained by the zeolite-bearing rock. For analysis the $\mathrm{NH}_{4}{ }^{+}$ions were converted to $\mathrm{NH}_{3}$. The sample was placed in a $100 \mathrm{~mL}$ Pyrex beaker containing a Teflon covered stirrer bar. $50 \mathrm{~mL}$ of deionised nitrogen-free water was added and the solution stirred to suspend the sample. The electrode was immersed in the suspension taking care to prevent the entrapment of air under the concave tip. Following the addition of $0.5 \mathrm{~mL} 10 \mathrm{M} \mathrm{NaOH}$, the amount of ammonia released was measured and the final value recorded when the reading became stable. The ammonia released was analysed by an ammonia gas electrode combined with a Jenway $3045 \mathrm{pH} / \mathrm{mV} / \mathrm{ion}$ analyser. Electrode calibration was performed daily using 10,100 and $1000 \mathrm{ppm}$ ammonium calibrating solutions provided by Jenway, in addition the electrode was checked hourly using the 100 ppm ammonium solution.

The mineralogical composition of the samples was determined semi-quantitatively by powderXRD (PXRD) method. PXRD analysis was performed using a Philips PW1710 diffractometer with $\mathrm{Ni}$-filtered $\mathrm{CuK}_{\alpha}$ radiation on randomly oriented samples. The samples were scanned from 3 to $43^{\circ}$ $2 \theta$ at a scanning speed of $1.2 \% \mathrm{~min}$. Semi-quantitative estimates of the abundance of the mineral phases were derived from the PXRD data, using the intensity (counts) of specific reflections, the density and the mass absorption coefficients of the elements for CuK $\mathrm{K}_{\mathrm{a}}$ radiation. Clay mineralogy 
was identified from air-dried, glycolated and heat-treated oriented samples scanned from 3 to $23^{\circ}$ $2 \theta$ at the same scanning speed.

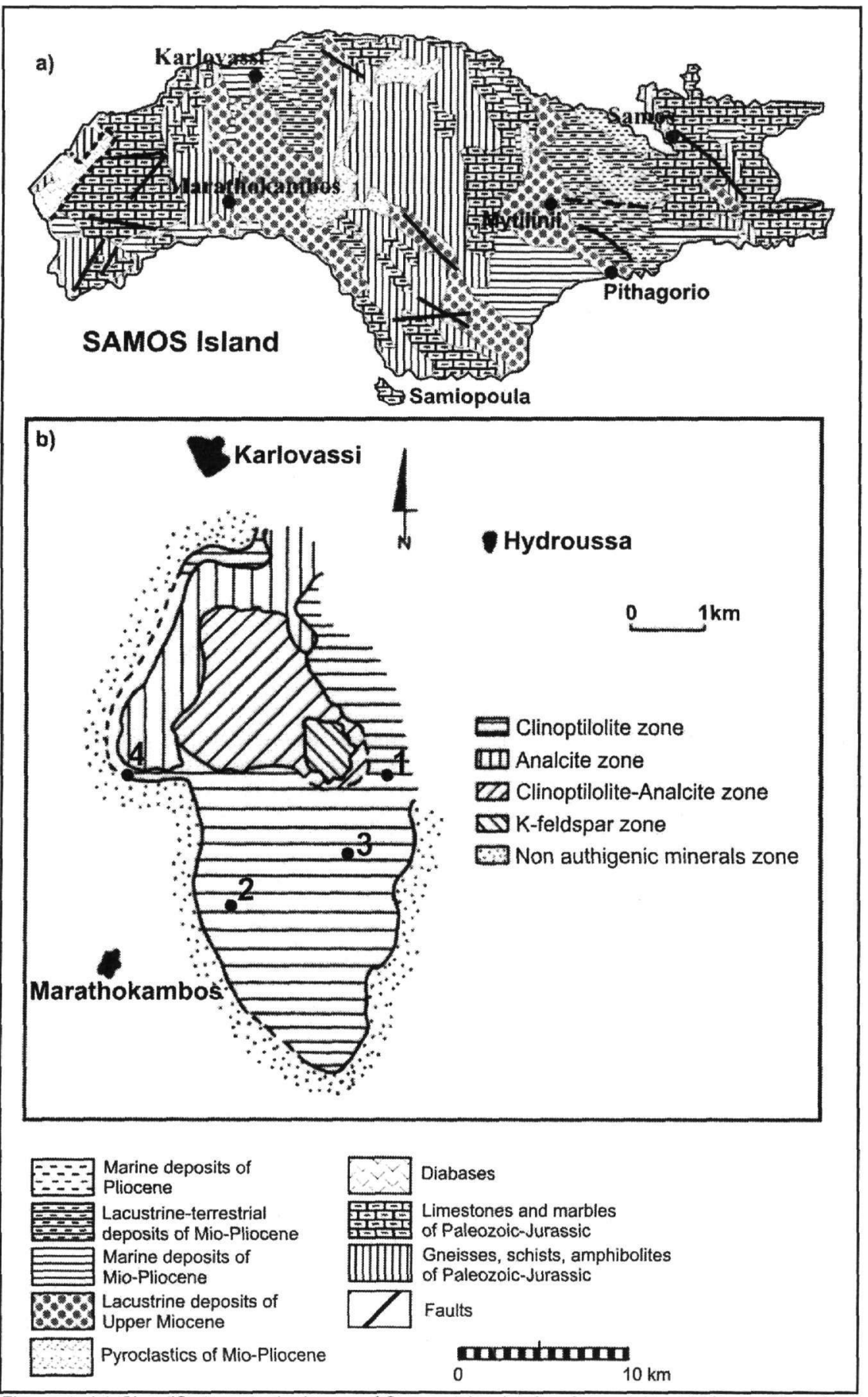

Figure 1. (a) Simplified geological map of Samos island (after Stamatakis 1989b and Kantiranis et al. 2002) and (b) locations of samples SA1-4. 
The chemical composition of the samples was measured by a Perkin Elmer 5000 Atomic Absorption Spectrometer with a graphite furnace following standard wet chemical methods.

\section{RESULTS AND DISCUSSION}

The chemical composition of the zeolite-bearing rock samples are presented in Table 1. All samples contained between 57.60 wt. \% (SA1) and 63.87 wt. \% (SA4) $\mathrm{SiO}_{2}$. The $\mathrm{Al}_{2} \mathrm{O}_{3}$ content varied from 12.68 wt. \% (SA2) to 14.77 wt. \% (SA1), and low amounts of $\mathrm{TiO}_{2}, \mathrm{MnO}, \mathrm{Fe}_{2} \mathrm{O}_{3} \mathrm{~T}$, and $\mathrm{P}_{2} \mathrm{O}_{5}$ were found. The total percentage of oxides of the exchangeable cations $\mathrm{Mg}, \mathrm{Ca}, \mathrm{Na}$, and $\mathrm{K}$ varies between 8.72 wt. \% (SA2) and 13,56 (SA1). Loss on ignition (at $1050^{\circ} \mathrm{C}$ for 2 hours) varied between 10.36 wt. \% (SA3) and 13.58 wt. \% (SA2).

Table 1. The chemical composition (wt. \%) of the Samos zeolitic rock samples.

\begin{tabular}{lllllllllllll}
\hline Sample & $\mathrm{SiO}_{2}$ & $\mathrm{Al}_{2} \mathrm{O}_{3}$ & $\mathrm{TiO}_{2}$ & $\mathrm{MnO}$ & $\mathrm{Fe}_{2} \mathrm{O}_{3} \mathrm{MgO}$ & $\mathrm{MaO}$ & $\mathrm{Na}_{2} \mathrm{O}$ & $\mathrm{K}_{2} \mathrm{O}$ & $\mathrm{P}_{2} \mathrm{O}_{5}$ & LOI $^{*}$ & Total \\
\hline SA1 & 57.60 & 14.77 & 0.13 & 0.05 & 2.73 & 2.74 & 3.02 & 0.73 & 7.07 & 0.03 & 11.23 & 100.10 \\
$\mathrm{SA} 2$ & 62.56 & 12.68 & 0.10 & 0.01 & 2.15 & 1.50 & 3.45 & 0.58 & 3.19 & 0.02 & 13.58 & 99.82 \\
$\mathrm{SA} 3$ & 59.56 & 14.11 & 0.12 & 0.01 & 2.75 & 1.47 & 1.92 & 2.07 & 7.21 & 0.02 & 10.36 & 99.60 \\
$\mathrm{SA4}$ & 63.87 & 13.13 & 0.08 & 0.02 & 1.96 & 1.10 & 2.18 & 1.45 & 5.66 & 0.02 & 10.50 & 99.97 \\
\hline
\end{tabular}

*Loss on ignition (at $1050^{\circ} \mathrm{C}$ for 2 hours).

The semi-quantitative mineralogical compositions of the zeolite-bearing ash tuffs and their uptake abilities are presented in Table 2 and Fig. 2. Clinoptilolite, micas (muscovite and/or Illite) and smectite constitute the microporous minerals of the zeolite-bearing rocks. The non-microporous minerals found in each sample are quartz and feldspars. This classification is based on their ability to sorb cations on their structure. The percentage of clinoptilolite varies between $47 \mathrm{wt}$ \% (SA4) and $74 \mathrm{wt.} \%$ (SA2). The total amount of muscovite/illite and smectite is comparable for all samples; it varies from $12 \mathrm{wt}$. \% (SA3) to $17 \mathrm{wt}$. \% (SA1), while the percentage of the total microporous minerals was found to be between 62 wt. \% (SA4) and 89 wt. \% (SA2).

Table 2. The semi-quantitative mineralogical composition (wt. \%) and the uptake ability (meq/100g) of the Samos zeolitic rock samples.

\begin{tabular}{llllllll} 
Sample & Cpt & M & Sm & TMM & Q & F & UA \\
\hline SA1 & 48 & 4 & 13 & 65 & 11 & 24 & 137 \\
SA2 & 74 & 13 & 2 & 89 & 6 & 5 & 184 \\
SA3 & 57 & 10 & 2 & 69 & 3 & 28 & 149 \\
SA4 & 47 & 12 & 3 & 62 & 3 & 35 & 133 \\
\hline
\end{tabular}

Cpt: Clinoptilolite, M: Micas (muscovite and/or illite), Sm: Smectite, TMM: Total microporous minerals $(\mathrm{Cpt+M+Sm),Q:} \mathrm{Quartz,} \mathrm{F:} \mathrm{Feldspars,} \mathrm{UA:} \mathrm{Uptake} \mathrm{ability.}$

The uptake ability of the studied samples was found to be between $133 \mathrm{meq} / 100 \mathrm{~g}$ (SA4) and $184 \mathrm{meq} / 100 \mathrm{~g}$ (SA2). Theoretical cation exchange capacity (C.E.C.) values for SA1-SA4 were calculated using values of 254 (meq/100g) for clinoptilolite, 20 (meq/100g) for muscovite and 100 (meq/100g) for smectite (Holmes, 1994; Deer et al., 1992). These theoretical C.E.C. values of 138 , 193,149 and $125 \mathrm{meq} / 100 \mathrm{~g}$ are in good agreement with the measured sample uptake abilities. 


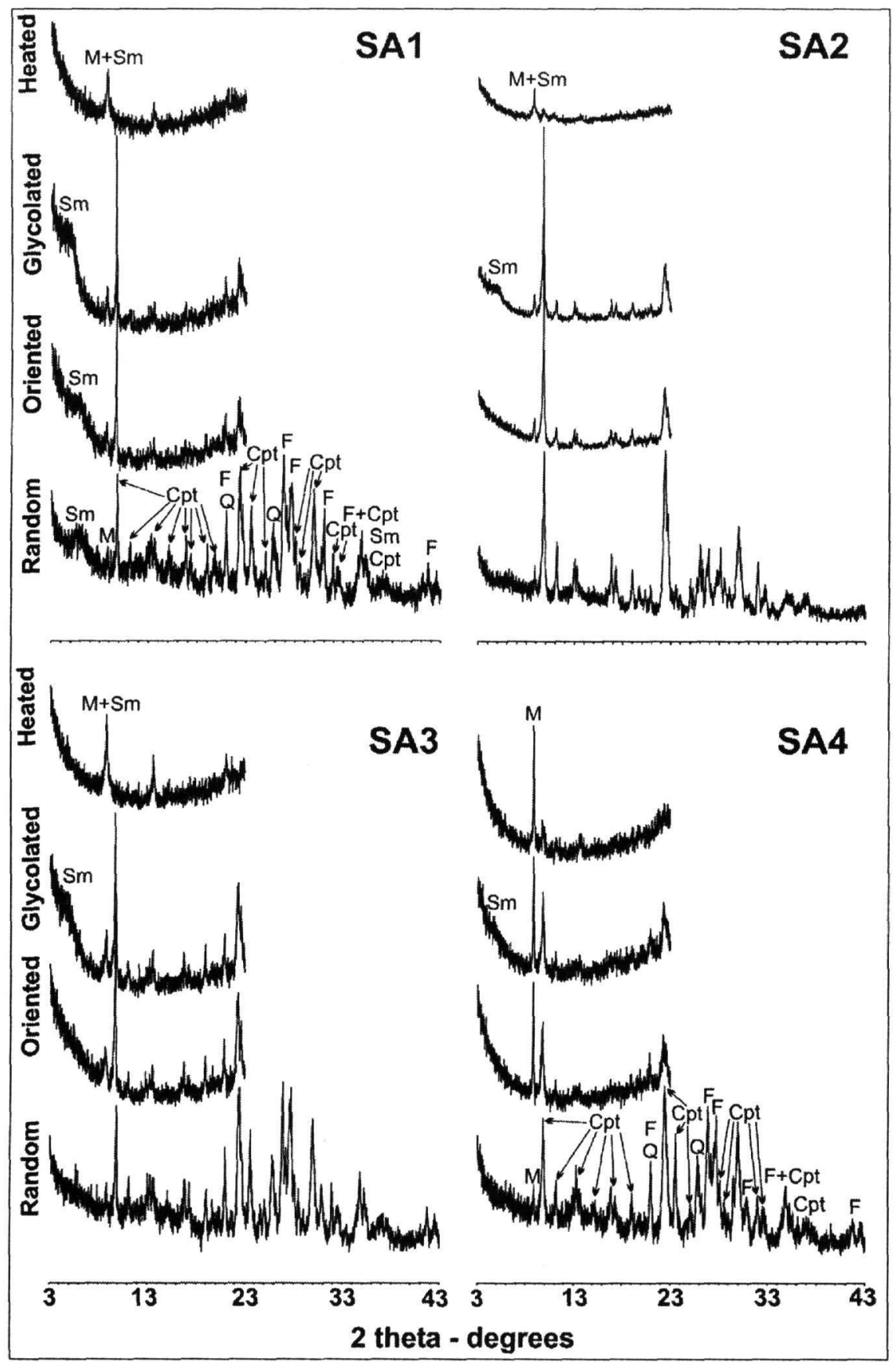

Figure 2. PXRD patterns and clay mineralogy of the studied zeolitic rock samples of Samos (Symbols as in Table 2)

The uptake ability of the studied samples increases with increasing wt. \% of clinoptilolite in the sample and as the wt. \% of the total microporous minerals increase. A good positive correlation $\left(R^{2}=0.9927\right)$ is observed between the uptake ability and the clinoptilolite content (Fig. 3). The high uptake ability of the clinoptilolite-rich tuffs of Karlovassi basin is in good agreement with similar measurements extracted from literature data (Skarpelis et al., 1993; Kantiranis et al., 2002). This 
behaviour is mainly due to the structure and physicochemical characteristics of the high silica and $\mathrm{Si} / \mathrm{Al}$ ratio of clinoptilolite compared with other zeolite materials. A good positive correlation, $\left(R^{2}=0.9937\right)$, is also observed between the uptake ability of SA1-4 and their total content of microporous minerals (clinoptilolite+muscovite/illite+smectite) (Fig. 4). Therefore, the uptake ability of the raw materials is highly dependent not only on the wt. \% of clinoptilolite but also on the wt. \% of the rest of the microporous minerals in the sample.

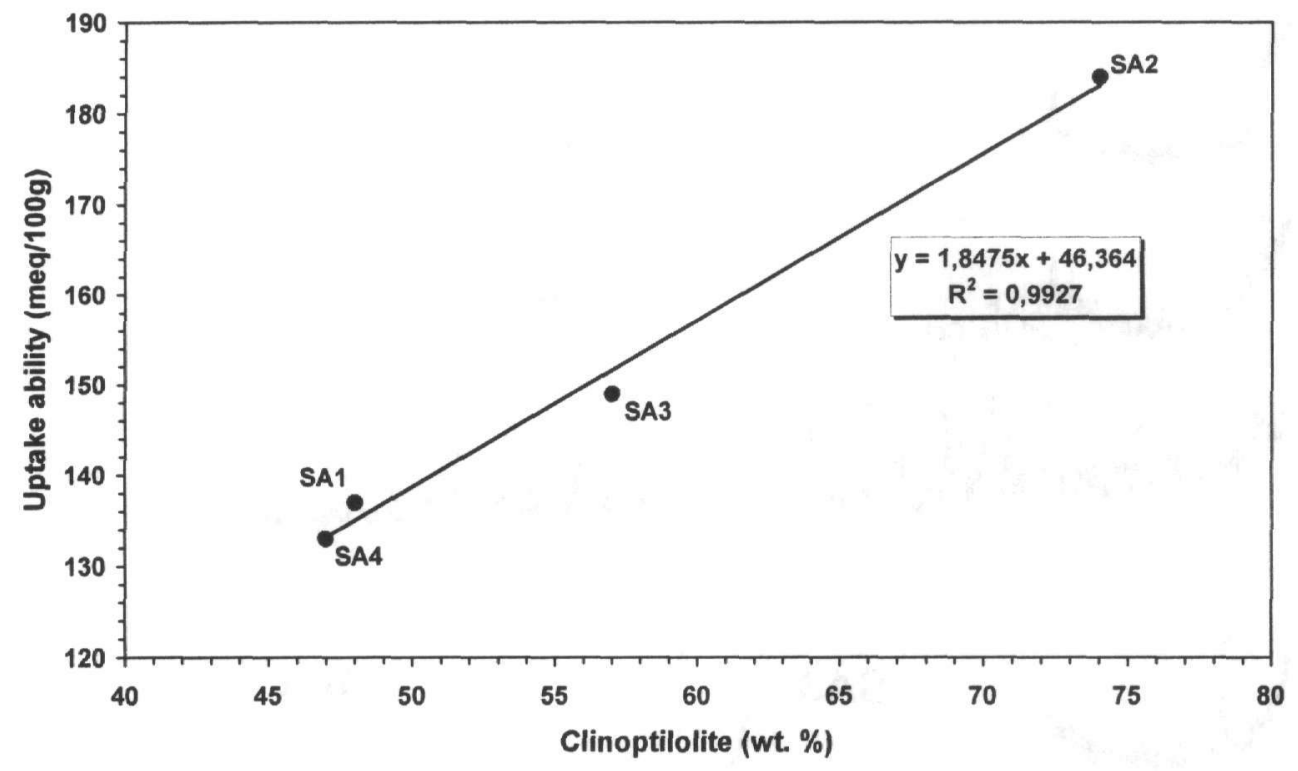

Figure 3. The uptake ability vs. the clinoptilolite content of the Samos samples.

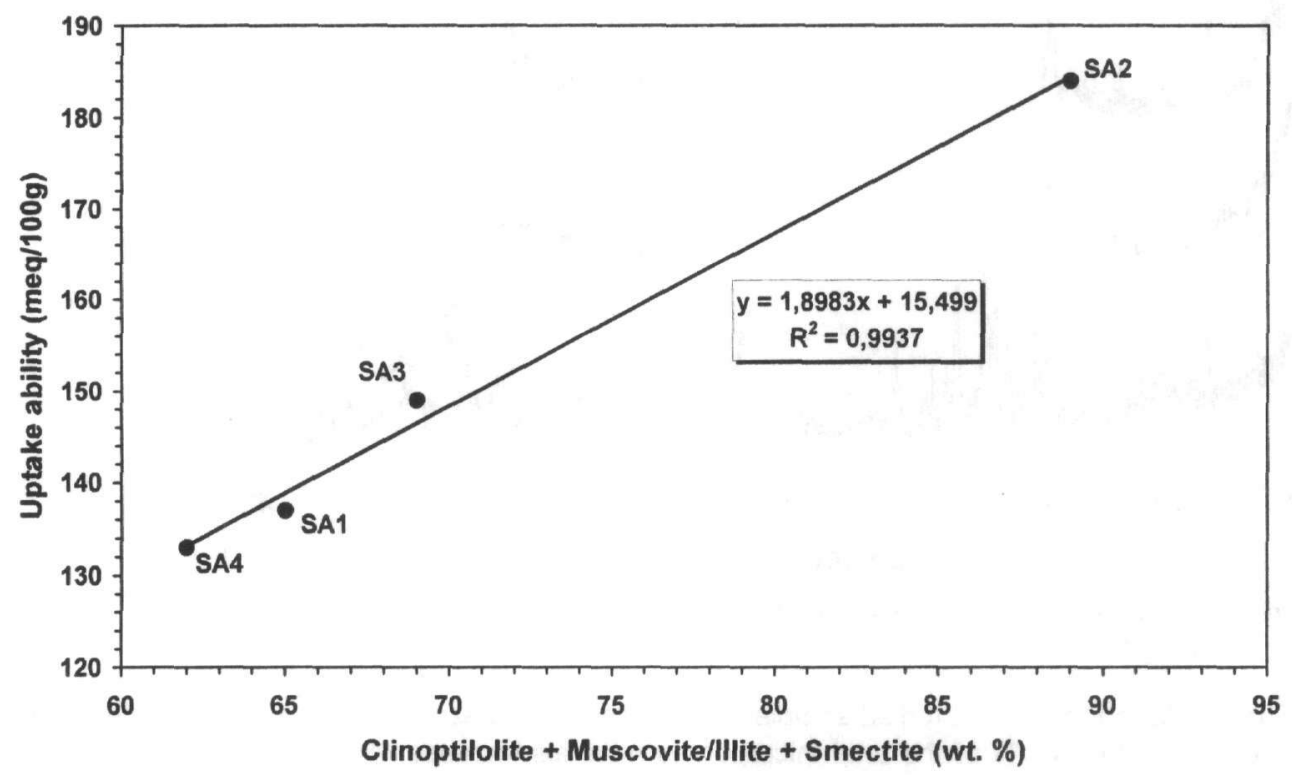

Figure 4. The uptake ability vs. the total microporous minerals (clinoptilolite+muscovite/illite+smectite) of the Samos samples. 
The measured uptake abilities gives the opportunity of utilizing the clinoptilolite-rich tuffs in a wide range of applications, such as, soil conditioner and fertilizer extender for agricultural products, animal nutrition, improvement of drinking water, purification, treatment and handling of civil, industrial and nuclear waste waters, purification and drying of gases, odour control, oxygen enrichment of air and water systems and in aquaculture (e.g. Pond and Mumpton, 1984; Tsitsisvili et al., 1992; Holmes, 1994; Tserveni-Gousi et al., 1997; Filippidis and Kassoli-Fournaraki, 2000; Yannakopoulos et al., 2000).

\section{CONCLUSIONS}

The four samples taken from different locations within the zone of clinoptilolite-bearing rocks on Samos Island each consist of clinoptilolite, muscovite/illite and smectite microporous materials and quartz and feldspar non-microporous materials in varying proportions. Clinoptilolite varies between 47 and $74 \mathrm{wt}$. \%. The uptake ability of the clinoptilolite-bearing rocks ranged between 133 and 184 $\mathrm{meq} / 100 \mathrm{~g}$ and is positively correlated with both clinoptilolite content and the total content in microporous minerals. The measured uptake abilities, gives the opportunity of utilizing the clinoptiloliterich tuffs of Samos, in a wide range of agricultural, aquacultural industrial and environmental applications.

\section{REFERENCES}

Bain, C. and Smith, L., 1987. Chemical analysis. In: Wilson M. (ed.), A handbook of determinative methods in clay mineralogy, Glasgow, Blackie, 248-274.

Barrer, R.M., 1978. Zeolite and Clay Minerals as Sorbents and Molecular Sieves, New York, Academic Press, 499pp.

Breck, D.W., 1974. Zeolite Molecular Sieves, Structure, Chemistry and Use, New York, J. Wiley, 771pp.

Deer, W.A., Howie, R.A. and Zussman, J., 1992. An Introduction to the Rock-Forming Minerals, $2^{\text {nd }}$ edn. London, Longman, 696pp.

Dermitzakis, M. and Papanikolaou, D., 1981. Paleogeography and geodynamics of the Aegean Region during

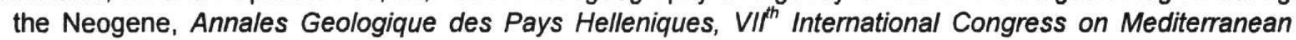
Neogene, Athens, 245-288.

Dyer, A., 1988. An Introduction to Zeolite Molecular Sieves, Chichester, J. Wiley, 149pp.

Filippidis, A., Godelitsas, A., Charistos, D., Misaelides, P. and Kassoli-Fournaraki, A., 1996. The chemical behavior of natural zeolites in aqueous environments; interaction between low-silica zeolites and $1 \mathrm{M} \mathrm{NaCl} \mathrm{so-}$ lutions of different pH-values, Applied Clay Science 11, 199-209.

Filippidis, A. and Kassoli-Fournaraki, A., 2000. Environmental uses of natural zeolites from Evros district, Thrace, Greece. In: Anagnostopoulos A. (Ed.), Proc. $5^{\text {th }}$ Int. Conf. on Environ. Pollution. 149-155, Thessaloniki, G. Korakidis Press, 1026pp.

Gottardi, G. and Galli, E., 1985. Natural zeolites, Berlin, Springer, 409pp.

Hall, A. and Stamatakis, M., 1992. Ammonium in zeolitized tuffs of the Karlovassi basin, Samos, Greece, Canadian Mineralogist 30, 423-430.

Holmes, D., 1994. Zeolites. In: Car D. (senior ed.), Industrial Minerals and Rocks, Michigan, Braun-Brumfield, Inc., Ann Arbor, 1129-1158.

Kantiranis, N., Filippidis, A., Mouhtaris, Th., Charistos, D., Kassoli-Fournaraki, A. and Tsirambides, A., 2002. The uptake ability of the Greek natural zeolites, ZEOLITE '02, 6th Int. Conf. on the Occurrence, Properties and Utilization of Natural Zeolites, Thessaloniki (June, 3-7 2002), 155-156.

Kassoli-Fournaraki, A., Stamatakis, M., Hall, A., Filippidis, A., Michailidis, K., Tsirambides, A. and Koutles, Th., 2000. The Ca-rich clinoptilolite deposit of Pentalofos, Thrace, Greece. In: Collela C. \& Mumpton F.A. (Eds.), Natural Zeolites for the Third Millennium, Napoli, De Frede Editore, 193-202.

Mercer, B.W. and Ames, Jr.L.L., 1978. Zeolite Ion Exchange in Radioactive and Municipal Watewater treatment. In: Sand L.B. \& Mumpton F.A. (Eds.), Natural Zeolites, Occurrence, Properties, Uses, Oxford, Pergamon Press, 451-459.

Merkle, A.B. and Slaughter, M., 1968. Determination and refinement of the structure of heulandite, American Mineralogist 53, 1120-1138.

Ming, D.W. and Mumpton, F.A., 1995. Natural zeolites '93: Occurrence, Properties, Use, International Committee on Natural zeolites, New York, Brockport, 622pp.

Mumpton, F.A., 1977. Mineralogy and geology of natural zeolites, Mineralogical Society of America, vol. 4, Virginia Blacksburg. 
Mumpton, F.A., 1978. Natural zeolites: A new industrial mineral commodity. In: Sand B.L. \& Mumpton F.A. (eds.), Natural zeolites: Occurrences, Properties, Uses. New York, Pergamon Press, 3-27.

Mumpton, F.A., 1988. Development and uses for natural zeolites: a critical commentary. In: Kallo D. \& Sherry H.S. (Eds.), Occurrence, Properties and Utilization of Natural Zeolites, Budapest, Akademiai Kiado, 333365.

Pe-Piper, G. and Tsolis-Katagas, P. (1991): K-rich mordenite from Late Miocene rhyolitic tuffs, Island of Samos, Greece. Clays and Clay Minerals 39, 239-247.

Pond, G.W. and Mumpton, F.A., 1984. Zeo-Agriculture: Use of Natural Zeolites in Agriculture and Aquaculture, Colorado, Westview Press, 305pp.

Skarpelis, N., Marantos, I. and Christidis, G., 1993. Zeolites in Oligocene volcaniclastic rocks, Dadia-Lefkimi area, Thrace, Northern Greece: Mineralogy and cation exchange properties, Bull. Geol. Soc. Greece $X X V I I I / 2,305-315$.

Stamatakis, M., 1989a. Authigenic silicates and silica polymorphs in the Miocene saline-alkaline deposits of the Karlovassi basin, Samos Island, Greece, Economic Geology 84, 788-798.

Stamatakis, M., 1989b. A boron-bearing potassium feldspar in volcanic ash and the tuffaceous rocks from Miocene lake depositis, Samos Island, Greece, American Mineralogist 74, 230-235.

Stamatakis, M., Hall, A. and Hein, R., 1996. The zeolite deposits of Greece. Mineralium Deposita 31, 473-481.

Theodoropoulos D. 1979. Geological map of Greece 1:50,000, Sheet Neon Karlovassi, IGME, Athens, Greece.

Tsitsishvili, G.V., Andronikashvili, T.G., Kirov, G.N. and Filizova, L.D., 1992. Natural zeolite. New York, Ellis Horwood, 274pp.

Tserveni-Gousi, A.S., Yannakopoulos, A.L., Katsaounis, N.K., Filippidis, A. and Kassoli-Fournaraki, A., 1997. Some interior egg characteristics as influenced by addition of Greek clinoptilolitic rock material in the hen diet. Archiv fur Getlugelkunde, 61(6), 291-296.

Tsolis-Katagas, P. and Katagas, C., 1989. Zeolites in pre-caldera pyroclastic rocks of the Santorini volcano, Aegean sea, Greece. Clays and Clay Minerals 37, 497-510.

Tsolis-Katagas, P. and Katagas, C., 1990. Zeolitic diagenesis of Oligocene pyroclastic rocks of the Metaxades area, Thrace, Greece. Mineralogical Magazine 54, 95-103.

Yannakopoulos, A., Tserveni-Gousi, A., Kassoli-Fournaraki, A., Tsirambides, A., Michailidis, K., Filippidis, A. and Lutat, U., 2000. Effects of dietary clinoptilolite-rich tuff on the performance of growing-finishing pigs. In: Collela C. \& Mumpton F.A. (Eds.), Natural Zeolites for the Third Millennium, Napoli, De Frede, 471-481. 